\title{
Burial society versus the Church in the Black society of South Africa: A pastoral response
}

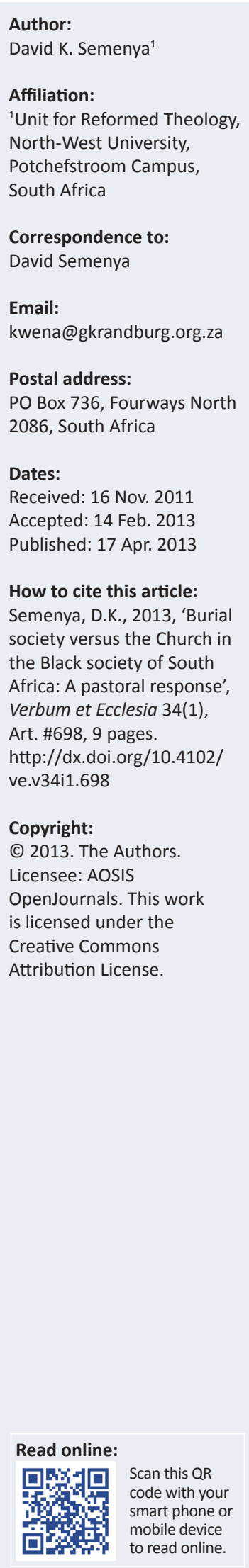

This article attempts to provide insight to the church councils of mainly Black churches, regarding members' absenteeism during Sunday church services and also the lack of financial contributions to the church. A number of church-going members are often absent on the last Sunday of the month or the first Sunday of the month because of their commitments to burial societies - burial societies prefer to meet on Sundays. Because the meetings take place at the end of the month and funding is one of the main issues at these meetings, the members' tithing to the church is negatively impacted. Our research found that members considered their contribution to the societies to be more important than their tithing to the church. In some cases members belonged to more than one burial society, and these members spent more money so as to receive greater support in the event of a death. Unfortunately this left them with nothing to give to the church. Another reason given for belonging to burial societies was that their membership helped them to prepare for death, would enable them to have a decent funeral service and would ensure that those who attended the funeral service did not go home hungry.

\section{Introduction}

South Africans value funeral insurance because of the cultural importance of having a proper funeral, which is an expensive all-day event. There is an extensive, informal funeral insurance industry and up to $19 \%$ of the population belong to burial societies ${ }^{1}$. It has been found that $81 \%$ of adults reported that they had contributed funds to a funeral society in the previous two years because of the high death rate prevalent in many Black communities. Singer (2003) argues that more South Africans belong to burial societies than any other community organisation, churches and sports groups included. According to Singer (2003), approximately one in four adults belong to a burial society.

Until recently burial societies in South Africa were associated with the elderly, but these days many young people also join burial societies (Tescher 2008; Singer 2003). It is argued that people now belong to burial societies from a younger age because of the scarcity of job opportunities and the increase in the mortality rate because of AIDS. They feel that burial societies will enable them to prepare for a decent burial. One cannot deny the fact that burial societies are able to help in situations where money is needed quickly because they are flexible and accommodating. In some burial societies members are eligible for small loans, and this is useful for people who normally cannot obtain a loan from other formal financial services. If a burial society can control such loans to its members, it may add value to the benefits to members (see also Molefe 1989; Lukhele 1990:55).

The burial society is a unique informal insurance scheme, designed to absorb some of the cost associated with the social events and cultural requirements of predominantly Black funerals. The burial society is defined as a local and relatively autonomous, historically distinctive mutual-aid institution, which may be occupationally or gender based, and which as the goal of providing social relief and support (material and non-material) to a member or member's family in distress because of a death. Burial societies are formed by people, mostly from the same community, to cover the costs of a member's funeral in the event of their death. In most cases members of the society must attend the night vigil and burial of other members who have passed on, and assist with the catering of the traditional burial lunch (Singer 2003; Deutcher Genossenschafts- und Raiffeisenverband [DGRV] 2003).

Furthermore, a burial society in its traditional form is a mutual-assistance scheme. As such it stands or falls by its ability to achieve reciprocity between members. In a 'traditional' burial society the members share risk by pooling their collective resources. Besides providing the funds for a coffin and funeral ceremony, burial society members may also supply and cook the food

1.The author wants to state it clearly that a burial society should not be confused with a stokvel. There is no fundamental difference between the two, and the words are sometimes used interchangeably. However, although the stokvel sometimes helps in times of bereavement, its activities are not restricted to burials. Burial societies, on the other hand, are only restricted to burial matters. The author will therefore only concentrate on forms of burial societies. 
required to feed the guests, relieve the bereaved family of any domestic work, and attend the traditional night vigil in honour of the deceased (Thomson \& Posel 2002).

Most of these informal burial societies are disregarded by the government and for that reason Abe Mkhize of the Insurance Sector Education and Training Authority (INSETA) said during the Burial Society Indaba in Johannesburg on 23 and 24 March 2010 that burial societies do not receive any assistance or any profitable returns from the government for the funds they invest. He called on the government to be flexible when formalising this sector (INSETA 2010). Burial societies are a well-known informal financial mechanism in South Africa, with an estimated membership of six million. It is, therefore, not surprising that this sizable market has attracted a great deal of attention from the formal financial and insurance sector. Several attempts have been made to formalise burial societies, with varying degrees of success. This is apparently due to the lack of a true understanding of the complex functioning of these institutions.

Singer (2003) says that even though South Africa is seen as one of the richest countries in Africa, it is characterised by the greatest disparity in wealth. South Africa has been plagued with the problem of large socio-economic inequalities, as a result of the Apartheid regime, and this phenomenon continues to manifest in the form of high rates of unemployment, poverty and crime. When writing about the history of burial societies, Ferreira (1983:1) states that burial societies are invariably directed at poorer and less educated people. She argues that in South Africa the disadvantaged, poor and less educated classes have historically been the Black and Coloured communities. It, therefore, comes as no surprise that burial societies tend to be more popular in these communities (DGRV 2003). In short, burial societies assist people when death strikes and help the bereaved to alleviate the financial problems they may face.

\section{Types of burial societies}

Most of the social collectives, including marriage societies, include burial assistance in their policies. There is a diverse range of societies in existence, but the following societies are the most common. Some of these burial societies are described below.

- Aretsebaneng [Let us know one another]: Only relatives are allowed to be members of this society. It covers events such as engagement parties, marriage ceremonies and funerals.

- Block society: People living in the same block of an area contribute money each month or if a special need arises. In the event of a death of someone in the block each block member must contribute the agreed upon amount within 24 hours. When the money has been collected, the funds are given to the bereaved family. This source becomes helpful to the family at that time.

- Street society: It is similar to the block society, but in this case only members living in the same street are allowed to join the society.
- Vegetable society: The members of this society contribute vegetables upon the death of a member or when a member performs an activity that falls within the scope of the policy of the society.

- Coffin society: The members of this society collect the funds for a coffin upon the death of a member.

- Cattle or chicken society: Members buy the cow, sheep or chicken for the funeral service.

- Grocery society: The members buy the groceries for the funeral, a party or a marriage ceremony of the relevant member.

- Hard and soft drinks society: Members buy the beverages for the marriage or party of a member. This kind of a society does not provide burial assistance, but does often provide refreshments for 'after tears' (celebration of friends and family members after the funeral). This 'after tears' party or 'wie sien ons' [who see us] in Afrikaans, as it is sometimes called, occurs after the burial of a loved one. The friends and family or members of the burial society gather, drink and dance to loud music to find relief of the pain they suffer because of the passing on of a loved one. The 'after tears' party is usually held at a neighbour's house or at a house obtained by the family for the event, since it is taboo to party at the house of the deceased right after death. In most cases the bereaved use some of the money received from the burial society to fund the 'after tears party', leaving them with little money for their own needs and those of the dependants of the deceased (see also Lukhele 1990:17). It can, however, be argued that no matter how painful it is to lose a beloved one, the bereaved does not have a right to grieve in the form of an 'after tears' party. There are many ways in which the bereaved may grieve in dignity for their lost ones.

- Eating utensils society: Members buy one another eating utensils on a rotational basis. This is done to ensure that members have enough eating utensils during ceremonies or when there is a death in the family.

- Cooking society: The members assist bereaved members with the cooking and other preparations for the funeral. This society also extends to parties or marriage ceremonies.

\section{Membership}

Some but not all societies are based on gender, for example, only men, women or young women. Membership is revoked when a member fails to contribute the amount agreed upon or even when a member does not attend meetings or the funeral services of other members.

\section{Uniform}

Most of the burial societies have a uniform they wear during their activities, for instance when they attend meetings or the funeral of one of their members. The uniform shows the unity of the members and is also a form of identity. It is, furthermore, a marketing tool in that the society's logo and motto are displayed on the uniform. Some have tags which help advertise who they are. 


\section{Meetings}

Societies normally meet on Sundays at 10:00 or in the afternoon at 15:00. Every member is obliged to attend the meeting or at least to send one of their family members to represent him or her at the meeting. Sometimes family members attend the meetings on a rotational basis. Members may also be fined for not attending a meeting. Saturdays are mostly reserved for other activities, such as housework or attending the funerals of members of the society. It is argued that meetings cannot be scheduled during the week, since most members get home late from work because of traffic congestion on the roads. Hence they meet on Sundays - and this affects attendance to worship services.

\section{Payments}

The DGRV (2003) reported that a group of people (mostly from the same area and/or family) make monthly contributions and also partial pay-outs to assist with funeral expenses. In most African societies, a dignified burial given by individuals or families to their next of kin and by also by communities to their members remains a very significant cultural event. As such, the ability of individuals to mobilise resources and provide social relief to a household in distress during the funeral process is very important in reconstituting family relations. Burial societies play a noteworthy role in making it possible for individual members to have direct access to, and control over, financial resources in such times of need (DGRV 2003). Some members of the societies pay an additional contribution to the societies in order to cover extended family members or even community members, to which they are not related, and when that member dies they refer to that person as lotto, 'Ke tshwere lotto' [This person has hit a lotto jackpot by dying]. Anyone who does not meet the agreed upon contribution is automatically erased from the books as a member of the society.

\section{Results}

In this section both the value of religion and of the burial societies for the people will be presented and discussed. Thereafter practical guidelines will be developed to assist members and church councils with the issue of absenteeism and the lack of financial contributions by society members to the church of God.

\section{Research methodology}

Heitink (1999:232) argues that if the researcher wants to acquire a deeper insight into the unique character of a specific conviction he or she has to make use of a qualitative interview. For that reason the author chose a qualitative method of research. Information about the people and their immediate environment was obtained by means of a number of interviews. Specific congregations were selected and since this issue affects most churches, churches of three different denominations and creeds were chosen for the interviews. The interviews were held in Diepsloot, northern Johannesburg, Gauteng Province and the following churches were selected for the interviews: Reformed Church, Methodist Church and
Zion Christian Church. The interviewees also varied in age and gender. The main focus of the interviews was to determine and evaluate the impact that burial societies have on the members of different churches. At the end of this article pastoral guidelines are given to assist members and their church councils on how to deal with the issue of burial societies.

All the questions of a previously structured questionnaire were explained to the interviewees and they were allowed to respond as they deemed fit (Heyns \& Pieterse 1990:78) (see Addendum 1). Participation was voluntary. The interviews were conducted in the language best understood by the group of participants and the researcher. ${ }^{2}$ The main reasons for doing so were to put participants at their ease and also to minimise misunderstandings or misinterpretations. The data obtained were then translated into English for presentation in this study. The data will be made available for a period of five years, for the sake of reference and verification.

Participants included one minister, one adult male, one adult female and two youth members, a boy and a girl, from each church to obtain a broader perspective. For the sake of identification and technicality the following symbols were used for the different categories:

- Congregation:

- $\mathrm{RF}=$ Reformed Church

- $\mathrm{MC}=$ Methodist Church

- $\mathrm{ZCC}=$ Zion Christian Church

- Interviewees:

- $\mathrm{MA}=$ man or adult male

- $\mathrm{WA}=$ woman or adult female

- $\mathrm{YM}=$ young male

- $\mathrm{YF}=$ young female

- $\mathrm{REV}=$ the minister of the congregation.

The participants remained anonymous, for the sake of confidentiality and out of respect for the congregations and their members.

This article presents the information gathered from each congregation, according to responses received to the questions. The information from the different congregations was merged and evaluated to identify certain themes as well as similarities and differences, in order to gain a better insight and a proper overview. The results of the interviews are then discussed and evaluated from a biblical perspective. Upon conclusion practical guidelines will be derived from positive biblical principles, to formulate a pastoral response with which churches can resolve absenteeism from Sunday church services and the lack of financial contributions to the church as a result of members' commitments to burial societies.

The individuals differed in age and gender to ensure a broader understanding. The questionnaires were used directly for the sake of order and formality. All the questions were open-ended to enable a wide range of responses and allow the participants the freedom to answer as he or she deemed fit.

2.The participants were of Basotho origin and they understood Pedi, South Sotho and Tswana. 
The following questions below were selected in order to obtain a better understanding of the issue of burial societies:

What do you think is the reason people join burial societies and, in most cases, more than one of them?

$\mathrm{RF}=\mathrm{MA}, \mathrm{WA}, \mathrm{YM}$ agreed with $\mathrm{MC}=\mathrm{MA}, \mathrm{WA}, \mathrm{YM}, \mathrm{YF}$, REV and ZCC = MA in supporting the idea that burial societies helped to ensure that they would have a decent funeral when they passed on. $\mathrm{ZCC}=\mathrm{REV}$ and $\mathrm{MC}=\mathrm{REV}$ continued by saying that the burial societies also offered financial support to the bereaved families. However, $\mathrm{ZCC}=\mathrm{WA}$ and $\mathrm{RF}=\mathrm{YF}$ saw no reason for a person to belong to more than one burial society, since the added attention it required would distract them from focusing their lives on Christ.

What do you think is the reason(s) that burial societies mostly meet on Sunday?

$\mathrm{RF}=\mathrm{MA}, \mathrm{WA}, \mathrm{YM}$ together with $\mathrm{MC}=\mathrm{MA}, \mathrm{WA}, \mathrm{YM}$ and $\mathrm{ZCC}=\mathrm{MA}, \mathrm{YM}, \mathrm{YF}$ responded that the burial societies met on Sundays because it was the one day that most of the members did not work and, therefore, had ample time to meet. $\mathrm{MC}=\mathrm{YM}$ argued that although Saturdays were available for most members, it was normally reserved for other activities such as funerals, weddings and housework. However, RF $=\mathrm{REV}, \mathrm{YF} ; \mathrm{MC}=\mathrm{REV}$ and $\mathrm{ZCC}=\mathrm{REV}$ felt that those who attended burial society meetings on Sundays during church services did not fear God, loved money and were not true Christians since it was possible to schedule the meetings before or after church services.

What do you think is of greater value: Burial societies or the Church of God? Provide reasons

$\mathrm{RF}=\mathrm{REV}, \mathrm{WA} ; \mathrm{MC}=\mathrm{REV}, \mathrm{WA}$ and $\mathrm{ZCC}=\mathrm{REV}$ agreed that attending church should be valued more, since it bought one closer to God and also prepared one for one's place in heaven. Furthermore the participants in essence argued that the church was important, since it was the place where one praised and gave thanks to the Lord. On the other hand, RF = MA, YM, YF and MC = YM, YF and $\mathrm{ZCC}=\mathrm{MA}$, WA argued that both of them should be valued, since burial societies offered financial support for the funerals of loved ones and the church comforted the bereaved, but that they should not interfere with each another. $\mathrm{RF}=\mathrm{WA} ; \mathrm{MC}=\mathrm{MA}$ and $\mathrm{ZCC}=\mathrm{YM}$, YF said only burial societies should be valued because of the support they offered in times of death.

What important role do you think the church plays in the life of a person and how would you compare that with the role that burial societies play in people's lives?

$\mathrm{RF}=\mathrm{REV}, \mathrm{WA} ; \mathrm{MC}=\mathrm{REV}, \mathrm{MA}, \mathrm{WA}$ and $\mathrm{ZCC}=\mathrm{REV}$, WA, MA answered that the church played an important role in the life of a person because it could lead him or her to God. It also edified, rebuked and comforted people every day of their lives and, moreover, it taught them the truth. People were then able to live in a manner pleasing to God, because they knew the Word of God. The church also helped in strengthening fellowship with God and fellow believers.

On the same note one could deduce from the participants' response above that they expected the church to play an important role in a life of a person because, according to their way of thinking, the person who only focused on burials societies would not inherit the Kingdom of God. Discord often erupted in the burial societies and they were a monthly expense.

$\mathrm{RF}=\mathrm{MA} ; \mathrm{YM}$; YF and MC = YM; YF and ZCC = YM, FY argued that both the church and burial societies should play an important role in a person's life, because the societies offered financial assistance at the time of a death and were especially welcome when the death occurred unexpectedly.

\section{How do you think one should prepare for death?}

Interestingly, $\mathrm{RF}=\mathrm{REV}, \mathrm{WA} ; \mathrm{MC}=\mathrm{REV}, \mathrm{MA}, \mathrm{WA}$, together with $\mathrm{ZCC}=\mathrm{REV}, \mathrm{WA}, \mathrm{MA}$, who all felt that a church played an important role in the life of a person, here argued that one attended church to maintain an intimate relationship with God, in respect of eternity, and also to prepare spiritually to deal with the agony that death would bring. They furthermore said that one should pray continually and believe wholeheartedly in God through our Lord Jesus Christ. It was no surprise that $\mathrm{RF}=\mathrm{WA} ; \mathrm{MC}=\mathrm{MA}$ and $\mathrm{ZCC}=\mathrm{YM}, \mathrm{YF}$, who had said that that only burial societies should be valued, repeated their argument here, saying that one should prepare for death by joining a burial society in order to be financially ready for funeral arrangements.

\section{Discussion}

The aim of the research was to provide to church councils and their members in mainly Black churches the reasons behind absenteeism at Sunday church services and the lack of financial contributions to the church.

Regarding the reasons that people join a burial society, and in most cases more than one, the results clearly indicate that most people do belong to burial societies and that they value the assistance they receive from them after a death. Although a number of participants did not see the need to join more than one burial society, they nevertheless agreed in essence that one should belong to at least one burial society.

One tends to agree with Singer (2003) when she states that the above argument can be the result of South Africa's current socio-economic structure. A review of these funeral schemes show that they are found amongst two race groups only, Black and Coloured communities. One could, therefore, conclude that the social imbalances in South Africa have contributed a great deal to this, since most people look for the means to be financially prepared for a death in the family and so they organise groups of burial societies. This is another way of taking care of the funeral expenses. 
Despite the fact that members benefit from the societies as they are given assistance in times of need, the time of their gatherings have a negative impact on the church attendance of members of different congregations, as well as the financial contributions by the members to the Church of God. Contributing financially to the church is one of the essential activities of members to show their love to their fellow believers. Contributing to the church is God's will. The purpose of contributing to the church is to meet the needs of the saints; to meet the needs of Christian workers and to meet the needs of the poor (cf. Lk 12:33-34; Eph 4:28; Jm 1:27).

Regarding the issue of burial societies meeting on Sundays, the results indicated that these societies regularly met on Sundays, since it was the day on which most of the members were available for meetings. During the week most people had to work and on Saturdays they attended funerals and other community activities.

However, other results indicated that people intentionally arranged burial society meetings on Sundays and that some members deliberately attended burial society meetings instead of church services. According to some of the participants those people did not fear God, since arrangements could have been made for the societies to meet before or after church services.

An in-depth review of the above arguments of the participants showed that although some of the participants did acknowledge Sunday as the day of the Lord, others did not really care about it. The Sabbath is on Sundays for Christians because Christ was crucified on a Friday and rose on the third day. Since Jesus' resurrection took place on the first day of the week, the day of worship was changed from Saturday to Sunday (cf. Ac 20:7). The thing one needs to keep in mind is that it should be a time for worship and if some time for rest can be included, that would be an added benefit.

\section{About the purpose of Sundays Wesley (2011) says:}

Sunday should be viewed as a holy day, set apart to the honour of the holy God, and to be spent in holy exercises. God, by his blessing it, had made it holy; they, by solemnly blessing him, must keep it holy, and not alienate it to any other purpose than that for which the difference between it and other days was instituted. Who must observe it? You; your son and your daughter. God has given us an example of rest after six days' work; he rested the seventh day - took complacency in himself, and rejoiced in the work of his hand, to teach us on that day, to take complacency in him, and to give him the glory of his works (cf. Gn 2:2-4).

The word 'remember' shows that this rule is not a new thing, but was also known in the past. One day in seven is to be kept holy. Six days are allotted to worldly business, but not so as to neglect the service of God and the care of our souls. On those days we must do all our work, and leave none to be done on the Sabbath day. Christ allowed works of necessity, charity and piety; for the Sabbath was made for man, and not man for the Sabbath (Mk 2:27), but all works of luxury, vanity or self-indulgence in any form are forbidden. The day is blessed; men are blessed by it, and in it. The blessing and direction to keep holy isn't limited to the seventh day, but is spoken of the Sabbath day (Henry 2011). In addition to that, one can conclude that although Sabbath is a blessed day, therefore this does not mean that man cannot dedicate other days of the week unto God, since each day it is a meeting between man and his God.

On the issue of what should be of greater value, burial societies or the church of God, the results strongly indicated that participants felt that the church should be valued more than the burial societies. The participants said that the church played an important role in the life of a person, because it could lead that person to God. It also strengthened fellowship with God and fellow-believers.

Some of participants, however, reasoned that they were both of value, since both played an important role in one's life. According to the participants both were of help in times of death and burial societies were especially welcome when death occurred unexpectedly.

According to the arguments of the participants above, one could say that the church offers spiritual support in the life of a person and that burial societies provide financial support. Yet burial societies should not be valued so highly that the church of God no longer has a place in the life of a person.

The church is the body of Christ, which he bought with his precious blood. Those who have been called by him should, therefore, always meet and celebrate his resurrection on the first day of the week. They should meet to receive God's teachings, to pray for one another and also to share their spiritual gifts. They should meet regularly to enjoy teaching and fellowship with other members. Our confession of faith rightly states in Article 28 that a church is an assembly of those who are saved, and outside it there is no salvation (Ursinus \& Olevianus 1979). This means that one may have a decent funeral, because of the burial societies, but if that person is not saved by Christ he or she will not inherit eternal life. Burial societies will never earn someone an eternal life, even though they play an important role in society.

Barnes (2011) and Clarke (2011) are of the opinion that the first church adhered to or attended the teaching or instruction of the Word of God. One of the signs of conversion was a desire to be instructed in the doctrines and duties of religion as well as a willingness to attend the preaching of the gospel. They had several things in common: participation, society and friendship. All Christians had the same hope of heaven, the same joys, the same hatred of sin, and the same enemies with which to contend and as such had the same subjects of conversation, of feeling and of prayer; or in other words they had communion in these things. They continued in prayer, knowing that they could only be faithful whilst they were upheld by their God and also knowing that they could not expect his grace to support them, unless they humbly and earnestly prayed for its continuance.

Regarding a proper preparation for death, the results of the research showed that the participants agreed that one should prepare for death by believing in God, through our Lord 
Jesus Christ, and that this would enable one to inherit eternal life. Some of the participants said that one also prepared for death by being financially ready for funeral arrangements and therefore by joining a burial society. Hence being a member of a burial society was vital.

Regarding the participants' views on preparing for death solely through financial assistance from burial societies, one can firstly look at what our Lord Jesus Christ said in John 5:24-27. He promised us:

Very truly I tell you, whoever hears my word and believes him who sent me has eternal life and will not be judged but has crossed over from death to life. Very truly I tell you, a time is coming and has now come when the dead will hear the voice of the Son of God and those who hear will live. For as the Father has life in himself, so he has granted the Son also to have life in himself. And he has given him authority to judge the living and the dead because he is the Son of Man.

Jesus plainly tells them that the only way to receive eternal life and avoid condemnation is to believe in him. He states that those who believe in him shall pass from death unto life (Abrams 2011). This shows that one has to prepare for death by believing in Jesus Christ. Although there are expenses when one dies, it should not be the primary issue. Burial societies are important, but not as important as readiness for one's death in a Biblical way.

\section{Positive and negative aspects of burial societies as deduced from the discussion above \\ Positive aspects}

It is evident from this study that burial societies offer financial support to the bereaved families. They cover the family and the extended family members and instalment rates are low. There is no restriction on age when one joins a burial society, whilst the coverage offered by banks has age restrictions. Banks also increase instalments when coverage for extended family members are sought.

Burial societies offer the quickest financial support in a situation where money is needed urgently for funeral preparations. There are no hassles with regard to paper work. Only a death certificate is needed and the money can even be given to the bereaved before a death certificate is obtained.

Some of the burial societies also give small loans to members. Some of the members cannot get loans from formal financial services. Loans are advantageous for the burial society because of the interest they get from loans and for the members who cannot obtain loans from formal financial institutions (see also Molefe 1989).

\section{Negative aspects of burial societies}

Burial societies have some disadvantages, however. In this study it was found that in most cases people joined burial societies to have a decent funeral but that the bereaved were left with nothing to support the dependents of a person who had passed on. The societies also prevented members of the church from regularly attending church services, since members of burial societies met on Sundays. This made it difficult for the members to prepare for death in a Biblical way. It was also evident from this study that members often belonged to more than one burial society; and that this made it difficult for the members to make financial contributions to their church. Moreover, the responses of members of the burial societies revealed that they tended to believe that one could only prepare for death by being a member of burial society.

The following practical principles will guide churches in assisting their members in matters relating to the burial societies:

\section{Practical guidelines Financial wellness course}

When church members belong to more than one burial society, their contributions to these societies dominate their budgets or salaries, with the result that they contribute less or nothing to the church of God and more to the societies. Therefore a financial wellness course would be necessary in this regard so as to offer members guidance with regard to their finances. This wellness course can be attended by all members, including church leaders.

\section{How can this be done?}

The church council should introduce a financial wellness course in the annual programme of the church. For the effectiveness of the course, the church council can agree to teach their members the course quarterly or as often as is deemed necessary. However, the church council should deal with the course in such a way that it is not reduced to a mere formality. The rhythm and commitment from both the members and the church council should be maintained and be monitored at all times.

The minister of the Word should also take part in the financial wellness programme, by teaching members a godly budget in which God is first and foremost on each and every member's budget. Elders and deacons or the church leaders should then enquire, during house visitation or small group gatherings, whether the members implement what they were taught during the financial wellness course. This will encourage members to contribute financially to the church of God, since they would be able to manage their finances well.

\section{Importance of attending the church service}

The members should be taught about the importance of attending the church services every Sunday, since most members are absent from church serv ices because of burial society meetings.

\section{How can this be done?}

The fourth commandment (Ex 20:8), which deals with the importance of attending the church services, should be 
taught by the minister during his sermons. The minister can also arrange a conference in which the fourth commandment is taught as a topic. This will assist members to honour the day of the Lord and keep it holy.

\section{Alternatives for meetings}

Burial societies are important and valuable in the lives of Black South Africans. Members should, therefore, be provided with alternatives so that it is possible for them to attend church services.

\section{How can this be done?}

Members of a burial society should at least make it a point that their money be deposited into a bank rather than meeting more often for the collection of money, as it is in most cases a major reason for the meetings.

Members should be encouraged to reduce the number of burial societies they belong to (members belong to burial societies that offer the same product), in a manner that will not have a negative impact on death benefits. The member could combine all of his or her burial societies and only contribute towards one that covers all death-related expenses. Burial societies in turn should offer a range of reasonable products (e.g. coverage for coffin as well as food). This will leave members with ample time to attend church services, since they wouldn't have so many burial society meetings. In other words, burial societies should improve their products and offer more options.

\section{Spiritual formation of members is important}

Members should be prepared spiritually to understand how important their relationship with Christ is. Members should be taught about life after death, which comes through our Lord Jesus Christ. The spiritual formation of members will make them value their spirituality above all else, including burial societies. Spiritual formation programmes should be introduced by the church council.

\section{How can this be done?}

Church councils should introduce courses on spiritual formation for all age groups. Whytock (2009) says:

Spiritual formation is a change. Change is not an option for the believers in Jesus Christ. We begin our new life by the Holy Spirit, and we are always reforming by the dynamic of the Holy Spirit. (p. 37)

\section{Sharing with the bereaved}

The church has to reemphasise its calling to be there for its members in every aspect of life. The New Testament teaches that there should not be any need amongst members of the church if there is a means of help. Members should be taught to share with the bereaved families, by at least bringing some gifts of love in the form of food. This will enable the bereaved to focus on bidding their last farewell to their loved one, rather than worrying about providing food for the funeral attendees. The early church extended their love to their fellow Christians by not only praying together, but also by sharing what they had (cf. Ac 2:41-47). This principle of the early church should also be practised by the current church.

\section{How can this be done?}

The church council should establish a service group concentrating on bereaved family members. This service group should concentrate on giving spiritual support as well as collecting food, which can be distributed to bereaved families in their time of need. The church council should also then encourage the congregants to give in order to fund the service group.

\section{Conclusion}

It is a fact that most Black people are affiliated to burial societies. The growing number of these burial societies is in itself a proof that they are important in the lives of Black people. Despite the fact that there are some disadvantages attached to them, such as keeping members of the church from attending church services and causing them not to contribute to the church, they offer assistance to their members when death strikes. However, members of the church have a responsibility towards their spiritual lives. Members should not only prepare for death by joining funeral societies; it is also important to prepare for death and the afterlife by believing in God through our Lord Jesus Christ, as this enables one to inherit eternal life. Therefore, the lack of financial contributions and absenteeism cannot be condoned by the church in this regard.

Burial societies will remain a challenge to the church of God since the members of the funeral societies are also members of the local churches. Therefore the above-mentioned practical guidelines should be used effectively by the church councils to offer guidance to their members.

\section{Acknowledgements Competing interests}

The author declares that he has no financial or personal relationship(s) which may have inappropriately influenced him in writing this article.

\section{References}

Abrams, C., 2011, 'A commentary on the gospel of John', in Bibletruth, viewed 09 March 2011, from http://www.bibletruth.org

Barnes, A., 2011, 'Notes on New Testament: The acts of the apostle chapter 2', in Studylight.org, viewed 09 March 2011, from http://www.studylight.org

Clarke, A., 2011, 'Commentary on Acts', viewed 09 March 2011, in Studylight.org, from http://www.studylight.org

Deutcher Genossenschafts- und Raiffeisenverband (DGRV), 2003, 'Burial societies in South Africa: History, function and scope', DGRV SA working paper series no 2 Agricultural Economics Consulting, Pretoria.

Ferreira, M., 1983, Burial aid societies and elderly coloureds in rural areas: some sociological comments on the dynamics of consumer exploitation within a culture of poverty, Human Sciences Research Council, Pretoria.

Heitink, G., 1999, Practical Theology: History, theory, action domains. A manual for practical theology, Zondervan, Grand Rapids, MI. 
Henry, M., 2011, Matthew Henry's concise commentary on the Bible, Exodus 20, Hendrickson, Peabody.

Heyns, L.M. \& Pieterse, H.J.C., 1990, A primer in practical theology, Gnosis, Pretoria.

Insurance Sector Education and Training Authority (INSETA), 2010, 'Burial societies call for skills development at indaba', in FANews, viewed 07 October 2010, from http://fanews.co.za/article.asp? Life-Insurance

Lukhele, A.K., 1990, Stokvel in South Africa: Informal savings schemes by Blacks for the Black community, Amagi, Johannesburg.

Molefe, S.P., 1989, 'Welfare provision by selected self-help organisations: An exploratory study, PhD thesis, Department of Social Work, University of the North.

Singer, R., 2003, 'In South Africa, death on the instalment plan', in The Body, 28 May, viewed 20 March 2011, from http://www.thebody.com
Tescher, J., 2008, 'Lessons from South Africa: Innovations and opportunities in underbanked services', in Centre for Financial Service Innovation (CFSI), viewed 09 March 2011 from http://www.cfsinnovation.com

Thomson, J. \& Posel, D.B., 2002, 'The management of risk by burial societies in South Africa',

South African Actuarial Journal 2, 83-128, Actuarial Society of South Africa, Cape Town. Ursinus, Z. \& Olevianus, C., 1979, Heidelberg Catechism, Andrew Murray Ward, Windhoek. PMid:543336

Wesley, J., 2011, 'Wesley's explanatory notes: Exodus 20', in Christ Notes, viewed 09 March 2011, from http://wwwchristnotes.org

Whytock, J.C., 2009, Study guide for spiritual formation, Centre for Reformational Urban Ministry in Africa (CRUMA), Kwa Mhlanga. 


\section{Addendum 1}

\section{Questionnaire}

1. Why do you think people join burial societies and in most cases more than one of them?

2. Why do you think burial societies mostly meet on Sunday?
3. What do you think should be of greater value: burial society meetings or attending church services regularly? Provide reasons.

4. What important role do you think the church plays in the life of a person and how would you compare that with the role that burial societies play in people's lives?

5. How do you think one should prepare oneself for death? 